\title{
Using a Second-Order Polynomial Model to Determine The Optimum Vinasse/Grape Marc Ratio For In-Vessel Composting
}

\author{
M.J. Díaz ${ }^{1}$, E. Madejón ${ }^{2}$, F. Cabrera ${ }^{2}$, L. Jiménez ${ }^{3}$ and M. De Bertoldi ${ }^{4}$ \\ 1. Departamento de Ingeniería Química, Facultad de Ciencias Lxperimentales Campus del Cammen, \\ Universidad de Hueloa, Hueloa, Spain \\ 2. Instituto de Recursos Naturnles y Agrobiología de Sevilla (CSIC), Sevilla, Spnin \\ 3. Departamento de Ingeniería Química, Campus de Rabanales, Universidnd de Cordoba, Espana \\ 4. Dept. of Industrial Microbiology, Unioersity of Udine, Udine, Italy
}

\begin{abstract}
This paper evaluates the influence of operating conditions $\left(\mathrm{pH}\right.$, Kjeldahl- $\mathrm{N}$ losses, $\mathrm{NO}_{3}^{-} \mathrm{N}, \mathrm{NO}-\mathrm{N}, \mathrm{C} / \mathrm{N}$ ratio and biodegradation) used in the vinasse/grape marc incubation on the properties of products obtained to determine the best incubation conditions (time and amount of vinasse proportion) to aid in the design of an in-vessel composting system. A second-order polynomial model consisting of two independent process variables was found to accurately describe, with $<10 \%$ differences between experimental values and model prediction, the vinasse-grape mare incubation. The dependent variables measured were $\mathrm{pH}$, Kjeldahl- $\mathrm{N}$ losses, $\mathrm{NO}_{3}-\mathrm{N}, \mathrm{NO}_{4}{ }^{-}-\mathrm{N}_{4} \mathrm{C} / \mathrm{N}$ ratio and biodegradation and the independent process variables were operation time and amount of vinasse. Results determined products with acceptable chemical properties, high biodegradation and germination index and minimum Kjeldahl-N losses entails operating at medium-to-short operation time (20-35 days) and medium-to-low vinasse pereentages (0-20\%).
\end{abstract}

\section{Introduction}

Beet vinasses are beet molasses almost completely biochemically desugarized, distilled and sometimes concentrated. Vinasse $(V)$ presents two main environmental problems: high organic load $(61000-70000 \mathrm{mg}$ $\mathrm{O}_{2} \mathrm{I}^{-1}$ ) and high salinity (EC 250)-300 $\mathrm{dS} \mathrm{m}^{-1}$ ) (López ê al. 1992). The high levels of $\mathrm{N}\left(30 \mathrm{~g} \mathrm{~kg}^{-1}\right), \mathrm{K}\left(30 \mathrm{~g} \mathrm{~kg}^{-1}\right)$ and organic matter $\left(350 \mathrm{~g} \mathrm{~kg}^{-1}\right)$ of the concentrated vinasse can be beneficial factors in recycling this waste for agricultural purposes. However, the direct application of vinasse to land has some drawbacks because of its high salinity, P content (P $0.06 \mathrm{~g} \mathrm{~kg}^{-1}$ ) and dense liquid character $\left(1.3 \mathrm{~g} \mathrm{~cm}^{-1}\right.$ ) (López et al. 1992).

Grape marc, a primary waste of wine production, could be recycled as a soil conditioner due to its organic matter $\left(850 \mathrm{~g} \mathrm{~kg}^{-1}\right)$ and nutrient contents ( $\mathrm{N} 15 \mathrm{~g}$ $\mathrm{kg}^{-1}, \mathrm{P}^{5} \mathrm{~g} \mathrm{~kg}^{-1}, \mathrm{~K} 10 \mathrm{~g} \mathrm{~kg}^{-1}$ ). The direct incorporation of grape marc into agricultural land, a common practice, has proved to be a serious problem since the degradation products can inhibit root growth duc to presence of phenols, tannins, etc. (Inbar, et al. 1991).

An alternative to overcome problems found in the direct application of vinasse and grape mare to soil and to recycle both products is cocomposting. The success of the composting process depends on several basic conditions including: the moisture content (5060\%) (Crawford 1983, Jeris and Regan 1973, a,b), offectiveness of the acration (Haug 1993, Choi 1999), the $\mathrm{C} / \mathrm{N}$ ratio of the initial mixture (20-30) (Kipp 1992), and reaching a temperature of 50-60'C (Shulze 1962; McGregor ef al. 1981; Mckinley of al. 1985; Stentiford 1996; Smårs et al. 1999). Another important parameter is the correct proportion of each material.

This work aims to elucidate the optimum vinasse/ grape mare ratio in order to determine the best composting conditions (operation time and vinasse) to achieve a correct composting design (adecuate physicochemical characteristics and minimum costs).

\section{Materials and Methods}

Relevant characteristics of the raw materials and initial mixtures are reported in Thable 1 . The experiments were carried out in plastic bins $(35 \times 20 \times 30 \mathrm{~cm})$. The walls and bottom of each bin were perforated with 100 $1 \mathrm{~cm}^{2}$ - holes. The mixtures (ca. $5 \mathrm{~kg}$ ) were placed in the bins and incubated in thermostatic chambers at $55^{\circ} \mathrm{C}$ provided by a blower $\left(70 / \mathrm{h}^{-1}\right)$ that delivered air continuously in the thermostatic chamber during the entire period of composting. A randomized complete block design with four replicates per mixture was used. Mois- 
TABLE 1

Chemical characterisation " of the raw materials, the initial mixtures and the final composts (day 50).

\begin{tabular}{|c|c|c|c|c|c|c|c|c|c|}
\hline & & & & & & $\begin{array}{l}\text { Mix } \\
20 \%\end{array}$ & $\begin{array}{l}\text { th } \\
\text { sse }\end{array}$ & $\begin{array}{r}\mathrm{Mi} \\
40^{\circ}\end{array}$ & $\begin{array}{l}\text { ith } \\
\text { asse }\end{array}$ \\
\hline & & $A V^{d}$ & $\mathrm{SD}^{\mathrm{e}}$ & AV & SD & AV & SD & AV & SD \\
\hline Day 1 & & & & & & & & & \\
\hline pH & & 4.7 & 0.4 & 6.8 & 0.6 & 5.2 & 0.5 & 5.0 & 0.7 \\
\hline$O M^{b}$ & $\mathrm{~g} \mathrm{~kg}^{-1}$ & 270 & 14.1 & 846 & 43.7 & 798 & 41.3 & 776 & 40.2 \\
\hline$N_{c}$ & $\mathrm{~g} \mathrm{~kg}^{-1}$ & 25.0 & 1.3 & 12.5 & 0.8 & 18.0 & 1.0 & 20.1 & 0.9 \\
\hline $\mathrm{NO}_{3}-\mathrm{N}$ & $\mathrm{mg} \mathrm{kg}^{-1}$ & 350 & 17.7 & 410 & 21.1 & 720 & 37.1 & 1120 & 58.0 \\
\hline $\mathrm{NH}_{4}-\mathrm{N}$ & $\mathrm{mg} \mathrm{kg}^{-1}$ & 50 & 2.6 & 10 & 0.4 & 20 & 1.1 & 35 & 1.9 \\
\hline $\mathrm{C} / \mathrm{N}$ & & 6 & 0.6 & 37.5 & 2.0 & 23.4 & 1.1 & 21.4 & 1.2 \\
\hline P & $\mathrm{g} \mathrm{kg}^{-1}$ & 0.3 & 0.1 & 3.1 & 0.4 & 2.0 & 0.5 & 1.9 & 0.4 \\
\hline K & $\mathrm{g} \mathrm{kg}^{-1}$ & 30 & 1.4 & 10.5 & 0.7 & 14.5 & 0.9 & 16.8 & 0.9 \\
\hline Ca & $\mathrm{g} \mathrm{kg}^{-1}$ & 3.4 & 0.5 & 27.3 & 1.1 & 26.3 & 1.3 & 28.5 & 1.3 \\
\hline $\mathrm{Mg}$ & $\mathrm{g} \mathrm{kg}^{-1}$ & 5.0 & 0.6 & 4.2 & 0.4 & 5.4 & 0.4 & 6.9 & 0.6 \\
\hline Day 50 & & & & & & & & & \\
\hline pH & & & & 8.2 & 0.5 & 8.0 & 0.4 & 8.1 & 0.7 \\
\hline $\mathrm{OM}$ & $g \mathrm{~kg}^{-1}$ & & & 695.0 & 36.1 & 667.0 & 34.6 & 666.0 & 34.3 \\
\hline $\mathrm{N}$ & $\mathrm{g} \mathrm{kg}^{-1}$ & & & 11.7 & 0.8 & 16.3 & 0.7 & 14.9 & 0.8 \\
\hline $\mathrm{NO}_{3}-\mathrm{N}$ & $\mathrm{mg} \mathrm{kg}^{-1}$ & & & 23.6 & 1.3 & 39.2 & 1.9 & 97.4 & 4.7 \\
\hline $\mathrm{NH}_{4}{ }_{4}^{\prime}-\mathrm{N}$ & $\mathrm{mg} \mathrm{kg}^{-1}$ & & & 3.0 & 0.5 & 4.0 & 0.7 & 5.0 & 0.5 \\
\hline $\mathrm{C} / \mathrm{N}$ & & & & 36.5 & 1.7 & 22.3 & 1.3 & 25.7 & 1.2 \\
\hline P & $\mathrm{g} \mathrm{kg}^{-1}$ & & & 3.4 & 0.5 & 3.3 & 0.5 & 3.1 & 0.3 \\
\hline K & $\mathrm{g} \mathrm{kg}^{-1}$ & & & 13.8 & 0.9 & 18.8 & 1.0 & 21.9 & 1.2 \\
\hline $\mathrm{Ca}$ & $\mathrm{g} \mathrm{kg}^{-1}$ & & & 28.7 & 1.5 & 27.4 & 1.5 & 30.7 & 1.5 \\
\hline $\mathrm{Mg}$ & $\mathrm{g} \mathrm{kg}^{-1}$ & & & 4.9 & 0.5 & 5.9 & 0.6 & 7.7 & 0.7 \\
\hline
\end{tabular}

${ }^{\mathrm{a}}$ Each value is the average of four samples, dry weight basis; ${ }^{\mathrm{b}} \mathrm{OM}=$ Organic matter; $\mathrm{C}=\mathrm{Kjeldahl-N}$; ${ }^{\mathrm{d}} \mathrm{AV}=\mathrm{Average}$; $\mathrm{SD}=\mathrm{Standard}$ deviation; ${ }^{\mathrm{f}} \mathrm{V}=\mathrm{Vinasse}$ ${ }^{8} \mathrm{GM}=$ grape marc

ture content was established at $55 \%$, for the initial mate rials during the thermophilie phase, moisture losses were compensaled by daily addition of waler and mannal mixing during incubation. By mass balance, after moisture characterization, the necessary water to maintain $55 \%$ of moisture was calculated. Particle size of grape mare $(<2.36 \mathrm{~cm})$ was the same for all experiments. Vinasse absorbed in the srape mare did nol modify the intial particle size. Ithe vinasse and the operation time of the different experiments of the factorial design were $(0 \%, 20 \%$ and $40 \%$ and 20,35 and 50 days respoctively.

Samples were collected and separated in two fractions (wet and dry analyses). Moisture was determined by drying at $105^{\circ} \mathrm{C}$ to a constant weight. For dry sample analyses, subsamples were dried $\left(60^{\circ} \mathrm{C}\right)$ and ground $(0-$ $25 \mathrm{~mm}$ ). The mixtures were analyzed, and results expressed on a dry matter basis, for the following parameters : pH $(1: 5 \mathrm{w} / \mathrm{v})$ using a $\mathrm{pH}$ electrode, total organic matter (OM) by loss on ignition $\left(550^{\circ} \mathrm{C}\right.$ for $5 \mathrm{~h}$ ) (Allison 1965), total P (acid digest) using the ascorbic acid method (APHA 1995), total K, Ca and Mg (acid digest) by atomic absorption spectrophotometry (APHA 1995), Kjeldahl-N (Bremnen 1996) and $\mathrm{NH}_{4}{ }^{+}-\mathrm{N}, \mathrm{NO}_{3}-$ $\mathrm{N}$ using the $\mathrm{KCl}$ extraction method (Mulvaney 1996) and germination index (Gi) was determined using seeds of Lepidium satioum L. The number of germinated seeds and the primary root length were measured and expressed as a percentage of the control. The Gi was obtained by multiplying the germination percentage by the root length percentage, divided by 100 (Zucconi et al. 1985). Biodegradation, a parameter that relates initial and final content of compost organic matter during composting, based on ash conservation (Haug 1993, Tchobanogolus et al. 1984), was also calculated for each mixture. Biodegradation, $\mathrm{K}_{\mathrm{b}}$, was calculated using the equation (Haug 1993).

where:

$$
K_{b}=\frac{\left[\left(O M_{i}-O M_{f}\right) 100\right]}{\left[O M_{i}\left(100-O M_{f}\right)\right]}
$$

$\mathrm{OM}_{\mathrm{f}}$ is the organic matter content $(\%)$ at the end of the process (dry matter basis) and

$\mathrm{OM}_{\mathrm{i}}$ is the organic matter content $(\%)$ at the beginning of the process (dry matter basis).

The Kjeldahl- N losises during the process have been calculated as perentages, based on the initial content of $N$-Kjeldahl, and the evolution of the organic matter, assuming the mineral amount in cach mixture is constant. 
The main factors controlling cocomposting systems include: cnvironmental parameters (temperature, moisture content, $\mathrm{pH}$, aeration, operation time) and substrate nature parameters (particle size, and nutrient contents).

The process parameters were fixed at the beginning of the experiment, excepting $\mathrm{pH}$, operation time and the vinasse (i.e. vinasse/grape mare ratio). Operation time and vinasse were selected as the independent variables. Time was selected due to its influence on the volume of the composting reactor. Vinasse proportion was chosen because of the imporlance of the amount of vinasse in the quality of the resulting compost. Kjoldhal- $\mathrm{N}$ losses, $\mathrm{NO}_{3}{ }^{-} \mathrm{N}, \mathrm{NH}_{4}{ }^{-}-\mathrm{N}, \mathrm{C} / \mathrm{N}$ ratio, biodegradation and $\mathrm{Gl}$ were the dependent variables, which were observed in relation to the independent variables. (iI was used as an indication of maturity because of its sensitivity to toxic substances and speed of germination.

\section{Experinental Design for the Incubation Process}

In order to relate the dependent ( $\mathrm{pH}$, Kjeldahl- $\mathrm{N}$ losses, $\mathrm{NO}_{3}-\mathrm{N}, \mathrm{NH}_{4}^{+}-\mathrm{N}, \mathrm{C} / \mathrm{N}$ ratio, biodegradation and germination index) and independent (time and vinasse) variables with the minimum possible number of experiments, a $2^{\mathrm{n}}$ central composite factor design for two factors was used that enabled the construction of second-order polynomials in the independent variables and the identification of statistical significance in the variables (Montgomery 1991, Aknazarova and Kafarov 1982). This design meets the general requirement that every parameter in the mathematical model can be estimated from a fairly small number of experiments. The total number of observations required $(\mathrm{N})$ for two independent variables (time and vinasse) was calculated using the following equation:

$$
\mathrm{N}=2^{\mathrm{K}}+2^{*} \mathrm{~K}+1 \ldots \ldots \ldots \ldots .
$$

where $\mathrm{K}$ is the number of independent variables, 2 in this design and therefore, $\mathrm{N}$ is 9 . The central combination for the experimental design was as follows: $t$ $=35$ days and vinasse $(V)=20 \%$. The results were subjected to multiple linear regression as implemented in SAS system package to discard non-significant variables, i.e. those variables with Snedecor's F coefficients values less than 4 (Aknazarova and Kafarov 1982). The independent variables values were normalized $\left(X_{n}\right)$ from -1 to +1 using equation 3 to improve the comparison of the coefficients and the visualization of the effects of the individual independent variables on the response surface. This normalization also resulted in more accurate estimation of the regression coefficients as it reduced interrelationships between linear and quadratic terms (Montgomery 1991).

$$
X_{n}=\frac{X-X}{\left(X_{\max }-X_{m, n}\right) / 2}
$$

where $X$ is the real value of a independent variable, ' $X$ is its average value and $X_{\max }$ and $X_{\min }$ are its maximum and minimum values, respectively.

The independent variables used in the equations relating to both types of variables were those having a statistically significant coefficient (viz. those not exceeding a significance level of 0.05 in Student's t-test and having a $95 \%$ confidence interval excluding $\%$ ero).

The amount of vinasse and operation time used in the different experiments of the central composite experimental design were $0 \%, 20 \%$ and $40 \%$ and 20,35 and 50, days respectively. Thus, normalized values of both the independent variable, " $X$ " (vinasse) and " $X_{1}$ " (time) were $-1,0$ and +1 .

\section{Results and Discussion}

Table 2 shows the normalized values of independent variables and its subsequent dependent variables of the products obtained in the incubation process, using the proposed experimental designs. Wach value in experimental results is an average of four samples. The deviations for these parameters from their respective means were all less than $5 \%$.

Multiple linear regression analysis yiclds the equations showed in Table 3 relating dependent variables as functions of independent variables. Plots in Figures 1-5 show the response surfaces for most representative dependent variables.

Figure 1 shows that the amount of vinasse has greater influence on $\mathrm{pH}$ than time. As this figure shows, $\mathrm{pH}$ slowly increases during the thermophilic phase at low levels of vinasse. However, at high vinasse levels, a different development was observed. The pl I values

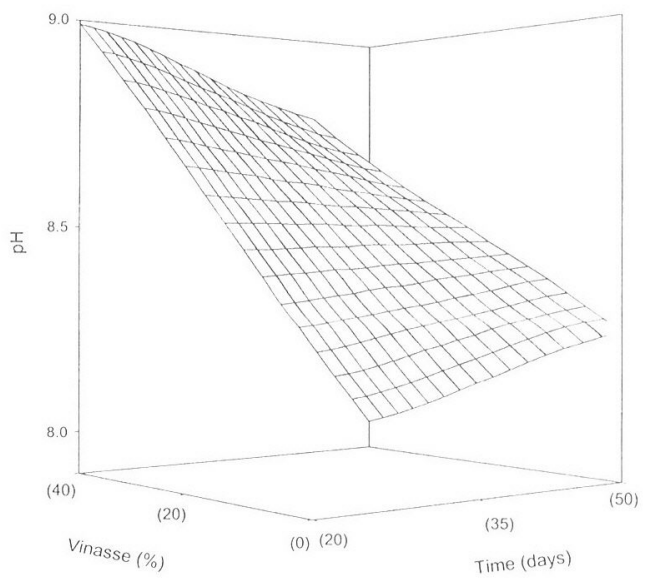

FIGURE 1. pH variation as a function of operation time and vinasse. 
TABLE 2

Values of the independent variables and the chemical properties of the mixtures obtained in the incubation process using the proposed experimental design

Normalized And Rea

Values Of Time And

Vinasse

${ }^{c} X_{1}{ }^{\mathrm{d}} \mathrm{X}_{v} \quad{ }^{\mathrm{e}} \mathrm{t} \quad{ }^{\mathrm{i}} \mathrm{A} \quad \mathrm{AV}^{\mathrm{g}}{ }^{\mathrm{pH}} \mathrm{SD}^{\mathrm{h}}$

$\begin{array}{lllllll}-1, & -1 & 20 & 0 & 8.56 & 0.50\end{array}$

$\begin{array}{llllll}0, & -1 & 35 & 0 & 8.45 & 0.68\end{array}$

$\begin{array}{llllll}+1, & -1 & 50 & 0 & 8.25 & 0.86\end{array}$

$\begin{array}{lllllll}-1, & 0 & 20 & 20 & 8.89 & 0.68\end{array}$

$\begin{array}{llllll}0, & 0 & 35 & 20 & 8.55 & 0.84\end{array}$

$\begin{array}{llllll}+1, & 0 & 50 & 20 & 8.01 & 0.75\end{array}$

$\begin{array}{llllll}-1, & +1 & 20 & 40 & 9.04 & 0.60\end{array}$

$\begin{array}{llllll}0, & +1 & 35 & 40 & 8.55 & 0.92\end{array}$

$\begin{array}{llllll}+1, \quad+1 & 50 & 40 & 8.07 & 0.44\end{array}$

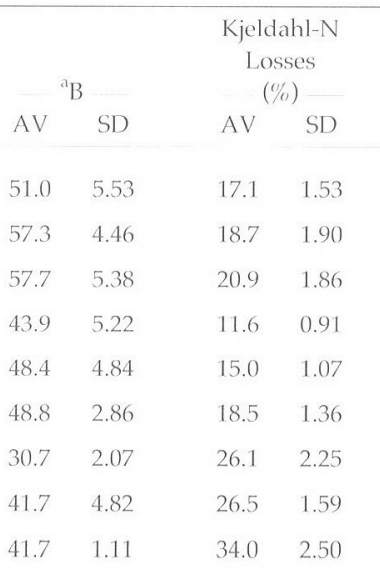

\begin{tabular}{cccc}
\multicolumn{2}{c}{$\mathrm{C} / \mathrm{N}$} & \multicolumn{2}{c}{$\mathrm{NH}_{4}{ }^{+}-\mathrm{N}$} \\
$\mathrm{AV}$ & $\mathrm{SD}$ & $\mathrm{AV}$ & $\mathrm{SD}$ \\
& & & \\
35.8 & 5 & 440 & 48.16 \\
35.5 & 3.79 & 2 & 0.13 \\
36.5 & 3.65 & 8 & 0.42 \\
21.0 & 2.69 & 450 & 47.71 \\
21.7 & 1.33 & 113 & 6.74 \\
22.3 & 1.27 & 3 & 0.32 \\
24.0 & 1.85 & 285 & 19.90 \\
23.6 & 0.77 & 50 & 3.82 \\
25.7 & 2.15 & 6 & 0.45
\end{tabular}

\begin{tabular}{|c|c|c|c|}
\hline \multicolumn{2}{|c|}{$\begin{array}{c}\mathrm{NO}_{3}^{-} \mathrm{N} \\
\left(\mathrm{mg} \mathrm{kg}^{-1}\right)\end{array}$} & \multicolumn{2}{|c|}{${ }^{\mathrm{b}} \mathrm{Gi}$} \\
\hline$A V$ & SD & AV & SD \\
\hline 70 & 5.34 & 36 & 2.29 \\
\hline 39 & 2.69 & 59 & 4.58 \\
\hline 31 & 2.02 & 80 & 7.22 \\
\hline 100 & 9.01 & 25 & 2.45 \\
\hline 65 & 6.37 & 44 & 3.40 \\
\hline 53 & 4.26 & 65 & 6.18 \\
\hline 158 & 11.16 & 16 & 1.59 \\
\hline 97 & 5.60 & 35 & 1.46 \\
\hline 98 & 10.39 & 51 & 2.22 \\
\hline
\end{tabular}

"Biodegradability; ${ }^{b} \mathrm{Gi}$ Germination Index; ${ }^{\mathrm{C}} \mathrm{Xt}$, normalized value of the operation time; ${ }^{\mathrm{d}} \mathrm{X}_{\mathrm{V}}$ normalized value of the vinasse; ${ }^{\mathrm{t}} \mathrm{t}$, real value of the operation time (days); $V$ real value of the vinasse $(\%) ;{ }^{8}$ AV Average; ${ }^{\text {h }}$ SD Standard deviation

TABLE 3 .

Equations yielded for each dependent variable

\begin{tabular}{llll}
\hline Eq. & & $r^{2}$ & $F$ \\
4 & PH $=8.48-0.37 X_{t}-0.16 X_{t} X_{v}$ & 0.93 & 40.0 \\
5 & $\mathrm{BIOD}=49.1+3.76 X_{t}-8.69 X_{v}-3.47 X_{t}^{2}$ & 0.98 & 65.4 \\
6 & $\mathrm{NL}=5.01+3.11 X_{t}+4.98 X_{v}+8.88 X_{v}^{2}$ & 0.97 & 48.5 \\
7 & $\mathrm{CN}=21.05+0.61 X_{t}-5.77 X_{v}+8.52 X_{v}^{2}$ & 0.99 & 367.4 \\
8 & $\mathrm{NO} 3=67-24.33 X_{t}+35.5 X_{v}+18.0 X_{t}^{2}$ & 0.92 & 34.3 \\
9 & $\mathrm{NI} 4=54.83-193 X_{t}+143 X_{t}^{2}$ & 0.96 & 42.5 \\
10 & $\mathrm{GI}=45.55+20.01 X_{t}-12.5 X_{v}-2.00 X_{t} X_{v}$ & 0.99 & 205.3
\end{tabular}

Where PII denotes $\mathrm{pH}, \mathrm{NL}$, the nitrogen losses (\%), CN the $\mathrm{C} / \mathrm{N}$ ratio, $\mathrm{NH}$ the $\mathrm{NH}{ }^{\prime}-\mathrm{N}$ content $(\mathrm{mg} / \mathrm{kg}), \mathrm{NO}$ the $\mathrm{NO}{ }^{-}-\mathrm{N}$ content $(\mathrm{mg} / \mathrm{kg})$, BIOD the biodegradability and $\mathrm{Gi}$ the germination index. $X$, and $X$ the normalized value of the operation time and vinasse, respectively. The differences between the experimental values and those estimated by using the previous equations never exceeded $10 \%$.

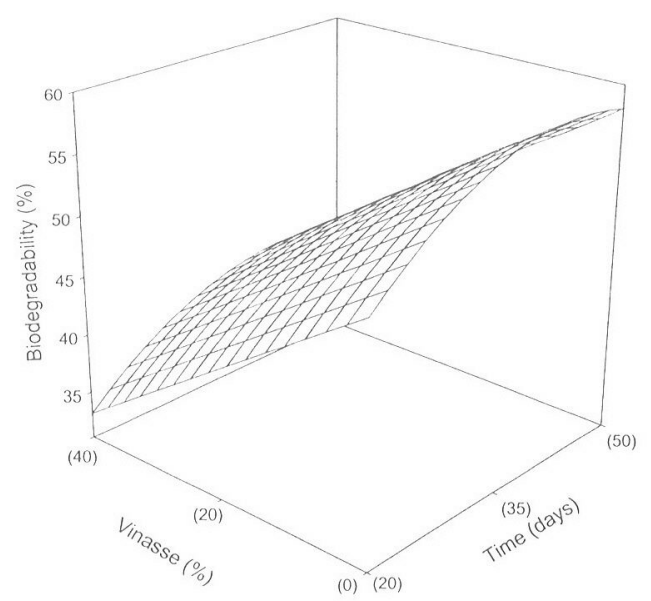

FIGURE 2. Biodegradability variation as a function of operation time and vinasse. decreased continually. Both evolutions could be due to loss volatilization of $\mathrm{N}$ as ammonia (Figure 3 ).

Biodegradation was similarly affected by both operation time and vinasse. In Figure 2 it can be observed that to obtain a high biodegradation, medium to long operation time (35-50 days) and low vinasse (0$20 \%)$ are recommended. The observed biodegradation values of the current mixtures was similar to those reported by other authors in similar residues $(22-71 \%$ for several residues, Kayhanian and Tchobanogolus 1992; (60-70\% for coffee and agricultural wastes, Nogueira et al. 1999).

Figure 3 demonstrates the large influence of the quadratic term in the vinasse factor in equation 7 (Table 3). The statistical influence of vinasse is

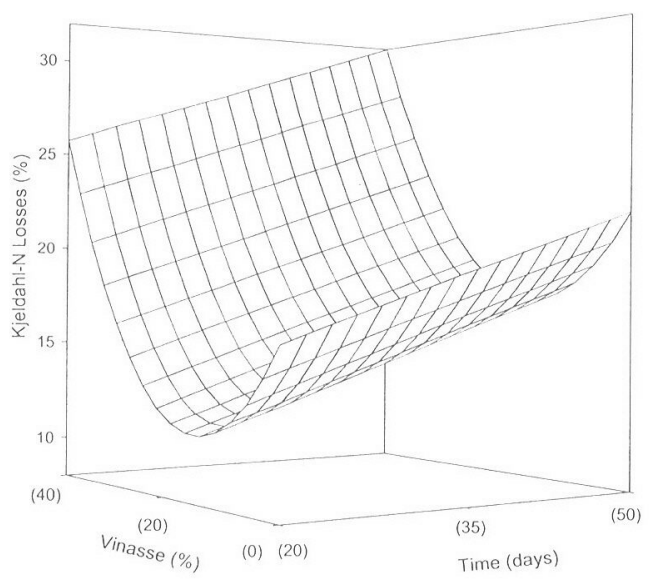

FIGURE 3. Kjeldahl-N loss variation as a function of operation time and vinasse. 
greater than that of the time (Figure 3). The initial values of Kjeldahl-N were significantly greater in the mixtures with higher proportion of vinasse, due to the relative high $\mathrm{N}$ content of the vinasse (Table 1). However, the final contents of Kjeldahl-N do not follow this same behavior. As it can be seen in Figure 3, lower losses of $\mathrm{N}$ took place in medium vinasse $(20 \%)$ ). The losses of $\mathrm{N}$ can be related with the $\mathrm{pH}$ evolution (Figure 1). Therefore, medium-tolow vinasse $(0-20 \%)$ could be used to reduce Kjeldahi-N losses. Although the initial $\mathrm{C} / \mathrm{N}$ ratio in the mixtures was higher than 20, important $\mathrm{N}$ losses were recorded during the process. This fact could be explained assuming that the available $\mathrm{C}$ for the microorganisms $\left(\mathrm{C}_{\text {biodegradable }}\right)$ is lower than the total $\left(\mathrm{C}_{\text {total }}\right)$, and therefore the $\mathrm{C}_{\text {bigdegradable }} \mathrm{N}$ ratio, is lower than the $\mathrm{C}_{\text {total }} / \mathrm{N}$ ratio (Digz, et al. 2002). The Kjeldahl-N losses in the present mixtures were similar to those reported by other authors in similar residues $(9-21 \%$ for wheat straw compost, Bannick and Joergensen 1993; 20-30\% for sorgum bagasse composts, Negro et al. 1999; 12-28\% for cattle decp litter composts, Sommer 2001).

The statistical influence of vinasse in the $\mathrm{C} / \mathrm{N}$ ratio is higher than that of the time (Eq 7 in Table 3). The optimum $\mathrm{C} / \mathrm{N}$ ratio of the initial mixtures is between 25-35 (Poincelot 1974, Haug 1993, Nakasaki et al. 1993, Choi 1999). Therefore, medium-to-low vinasse $(0-20 \%)$ was recommended. The $\mathrm{C} / \mathrm{N}$ ratio decreased during the composting process to reach of 10-15 - typical values of finished compost (Poincelot 1974, Rao et al. 1995). Due to positive and negative statistical influence of the vinasse term in $\mathrm{C} / \mathrm{N}$ cvolution (Eq. 7 in Table 3), to obtain low $\mathrm{C} / \mathrm{N}$ ratios for final mixtures medium-to-low vinasse $(0-20 \%)$

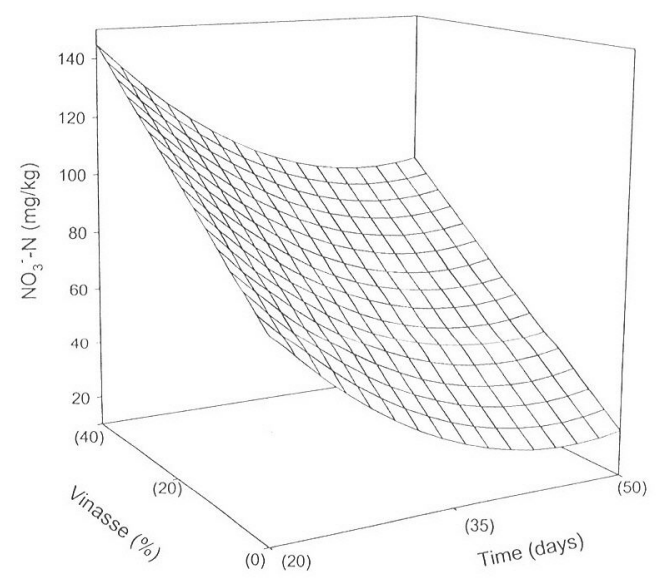

FIGURE 4. $\mathrm{NO}_{3}-\mathrm{N}$ variation as a function of operation time and vinasse. should be used. The operation time could be medium-to-short (20-35 days) due to its scarce statistical influence (Eq. 7 in Table 3). Long operation time could give rise to greater investment and maintenance costs.

The statistical influence of vinasse on $\mathrm{NO}_{3}{ }^{-} \mathrm{N}$ final values was higher than that of the operation time (Figure 4). Final values $\mathrm{NO}_{3}-\mathrm{N}$ increased as vinasse increased and decreased as operation time increased. Ilowever, equation (Table 3 ) shows no statistical influence of the vinasse on $\mathrm{NH}^{\prime}-\mathrm{N}$ final values. $\Lambda$ the same time, Eq. 9 shows that to obtain suitable $\mathrm{NH}^{1}-\mathrm{N}$ values, long operation time (50) days) should be recommended. A high $\mathrm{NO}_{3}-\mathrm{N}$ content of the mixtures at the beginning of incubation was observed (Table 1). This fact could be attributed to initial nitrogen mineralization of the substrates during their storage. Figure 4 shows that the $\mathrm{NO}_{3}-\mathrm{N}$ decreased in the initial phases of the thermophilic incubation and then, slightly increased during the final phase of the process. Therefore, to obtain high $\mathrm{NO}-\mathrm{N}$ contents in the final product, high vinasse $(40 \%)$ should be used. Other authors reported similar $\mathrm{NO}_{3}{ }^{-} \mathrm{N}$ evolution during composting (Bishop and Godfrey 1983, De Bertoldi et al. 1985, Mahimairaja et al. 1994). The content of $\mathrm{NH}_{4}{ }^{2} \mathrm{~N}$ in the final products was lower than the value advised for mature compost (40 mg/ kg, Zucconi and De Bertoldi 1987, Mathur et al. 1993). The decreased of $\mathrm{NH}_{4}$ $\mathrm{N}$ during the process did not correspond with an increase of $\mathrm{NO}_{3}-\mathrm{N}$, suggesting that $\mathrm{N}$ was lost during incubation. Probably, most of the NII was lost through $\mathrm{NH}_{3}$ volatilization due to the high temperature $\left(55^{\circ} \mathrm{C}\right)$ and $\mathrm{pH}$ values $(>7)$.

Figure 5 shows the variation of the germination

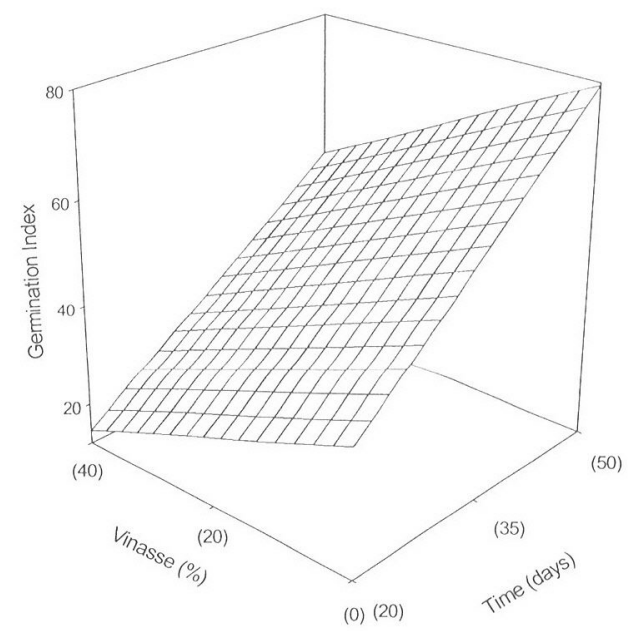

FIGURE 5. Germination Index (Gi) variation as a function of operation time and vinasse. 
index (Cii) as a function of time and vinasse. Phytoloxicily decreased, or (ii increased, in all cases during the incubalion. From the Equalion 1 ( Table 3 ), it can be deduced that the positive statistical influence of the operation time is higher than the negative statistical influence of the vinasse proportion. If a high (cii) is desired, a medium-lo high operation time (3550 days) and modium to-low vinasso (0-20\%) should be used. lior low vinasse mixtures, intermediate opcration time (35 days) was enough to ensure a suitable maturity (Ci o60) (\%uconi at al 1985).

The initial (day (1) and final (day 50) nutrients content in mixtures are shown in Table 1 . As the amount of vinasse increases in the initial mixtures, concentrations of $K$, Cand $M g$ increased and concentration of l' deoreased. Increases of nutrient con cents were observed at the end of composting, probably becase the decrease of organic matter concentration.

For economic reasons, medium operating time 35 days) is recommended. At an operating time of 35 days, $20 \%$ of vinasse represents the point in the experimental designal which the ration of biodegradation to nitrogen loss (i.e. maximum degradalion with minimum nilrogen losis) is highest (3.22). I Ienoe, this could bo a suitable combination for in-vessel composting.

\section{Conclusions}

The results of the experiments indicated that composting of vinasse and grape mare can be considered as an ecological way of recycting these wastes. Results of the incubalion experinent show that a final product (compost) with acoeplable propertices (maturity and chemical) entails operating at medium operalion time (20-35 days) and medium10.. low vinasse (0)-20\%). Moderate amount of vinasse (10-20\%) would be the best compromise lo compost this wasto with grape mare.

\section{Referencess}

Akhnazarova, 5. and $V$. Kafarov. 1982. lexperiment optimizalion in chemistry and chemical onginoring. Mir Jublisher. Moscow.

Allison, 1.1L. 1965. Organic (aldon. In: Black R. (ed.). Mothods of Soil Amblesis. SSSA, Madison, WI, Vol II, pp. 367-378.

APlIA (American Public I lealth Association). 1995. Standard Methods for the lixamination of Walcr and WasteWaller. APIA. Washinglon, I).

Bannick, C.C. and R. G. focroensen. 1993. Chanese in N fractions doring composting of whoul straw. Biology and lieffility of Soils 16:269-274

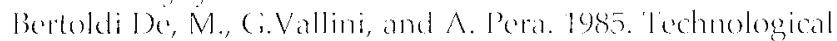
Aspectsol composting including Modelling and Microbiology. In: (iasser, J.K.R. (cd). comprosting of Agricullur-
"It and obler anstes lilsevier Applied Science l'ublishers, london, pp. 27-40.

Bishop, P'I. and ('. Codfrey. I983. Nitrogen Iransformalions during sludge composting. Biocyde. $23(7): 34-39$

Brommen, J.M. 1996. Nitrogen-Tolal, Ln: Sparks I).I. (cod). Melhods of Soil Analysis. $5 \operatorname{sis}$, Madison, WI, Vol 111 , pp. $1085-1121$

Choi, K. 1999. Oplimal operating paramelers in the com posting of swine manure with wastepaper. / lmowon Sot Hewllh B, $31(6): 975-987$.

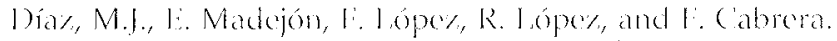
2002. Optimization of the rate vinasso/grape mare for cocomposting process Process Biodhem., 37: 1 143-1150.

Chawhord, J.11. 1983. Composting of agricultural wastes-A review. Process Bioghem. 16: 14-18.

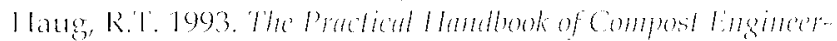
ing. lewis Publishers. Boca Raton, lilorida, USA.

lnbar, Y., Y. Chen, and Y. lladar. 1991. Carbon-13 CPMAS NMR and F"lTR spectroseopic analysis of organic maller transformations during composting of solid wastes from wincries. Soll Sit, 152: 272-282.

Jeris, J.S. and R.W. Regan. 19\%a. Controlling Lnvironmenlal Parameters for Oprimun Composting. l'art l. Comprost Sit., 14 (Jan-lisb): 1015.

Joris, I.S. and R.W. Rogan. 1973h. Controlling Lnvitommen tal Parameters for Optimun Composings. P'art Il. Com pest Sit. 14 (March $\wedge$ pril): $8-15$

Kayhanian, M. and Ci. 'l'chobanogrous. 1992. Compulations of $(\mathrm{N}$ ratios for various organic fractions. Biocucte, 33 (5): $58-60$

Kipp, C.L. 1992. Optimun process paramelers for compost ing sludge. Biociste, 25 (9): 34.40.

1.6po\%, R., 1. Cabrera, and J.M. Murillo. 1992. Lffect of beet vinasse on melish seceding emergence and fresh weight production. In: I opere Gillves.). (cot.). Intornationnl silm-

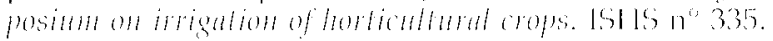
Almoria. Spain.

Mahimairaja, S., N.S. Bohan, M.J. Hedley and A. N. Mecire-

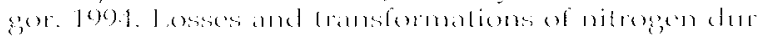
ing composting of pouldry mancere with difforent amendments: an incubalion experiment. Biores. Tedt. $1101 ., 47: 265-273$

Mathur, S.1', (i. Owen, 11. 1)inel and M. Schnitzer. 1993. I) termination of compost biomaturity. I. I,iterature rewiew. Biol Agr. Horlic, 10:65-85.

Mecregor, S.'., F.C. Miller, K.M. J'sartanos and S. Jinstein. 1981. Composting Process Control Based on lnteration

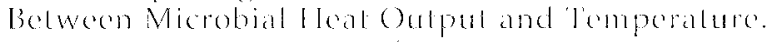

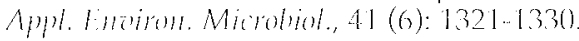

Mckinfey, V.I.., J.R. Vestal and A.J Jiralp. 1985. Microbial Activity in Composting (I). Brocyde, 26 (9): 39.43.

Montgomery, D.C. 1091. I)iseno y análisis de exporimentos. Editorial lberoamericana, México.

Mulvancy, R.1. 1996. Nitrogen-inorginnic lorms, /n: Sparks D.1. (ed.). Methods of Soil Andlysis S5SA, Madison, WI, Vol III, PP. 1123-[13\%.

Nakasaki, K., II. Yagushi, Y. Sasaki and II. Kubota. 1993. BIfact of pla control composting of garbage. Werte Manteg. $R e s, 11(2): 117-125$.

Negro, M.J., M.L. Solano, P. (iria, and J. Carrasco, 1999. Composting of sweel sorghum bagasse with othor wastes. Biores. Tedmol., 67:8992.92.

Nogucira, W.A., F.N. Nogucira and D).(. Dovens. 1999. Temperature and pll comtrol in composting, of coffer 
and agricultural wastes. Wat. Sci. Technol, 40 (1): 113119.

Poincelot, R.P., 1974. A Scientific Examination of the Principles and Practice of Composting. Compost Sci., 15 (Summer): 24-31

Rao, N, H.E. Grethlein and C.A. Reddy. 1995 Effect of C/N ration and moisture content on the ocmposting of poplar wood. Biotech. Let., 17 (8): 889-892.

Schulze, K.L. 1962. Continuous Thermophilic Composting. Appl Microbiol. 10: 108-122.

Smärs S., B. Beck-Friis, H. Jönsson and H. Kirchmann. 1999. Influence of temperature during the initial phase of composting on biological activity and emission of ammonia and dinitrogen oxide. In: Bidlingmaicr, W. et al., (eds.). Proceedings of the International Conference ORBIT 99 on Biological Treatment of Waste and the Environment. Rhombos-Verlag, Berlin, pp. 119-122.

Sommer, S.G. 2001. Effect of composting on nutrient loss and nitrogen availability of cattle decp litter. Lurop. I. Agron., 14: 123-133.

Stentiford, E.I. 1996. Composting control: Principles and Practice. In: De Bertoldi, M. et al., (eds). The Scionce of Composting. Blackie Academic \& Professional, I,ondon, UK. Vol li, pp 49-59.

Tchobanogolus, G., H. Theisen, and S. Vigil. 1984. Cestión integral de residuos sólidos. Ed. Mc Ciraw-Hill, Madrid.

Tiquia, S.M. and N.F.Y. 'Tam. 2000. Fate of nitrogen during composting of chicken litter, Emzirom. Poll., $1 \mathrm{~T}$ (): 535-54.1.

Zucconi F., A. Monaco and M. Forte. 1985. Phytoloxins during the stabilisation of organic matter. III: Cassier J.K.R. (ed). Composting of Agricultural and other Wastes. Elsevier Applied Science Publications, I ondon, UK, pp. 73-85.

Zucconi, F. and M. De Bertoldi. 1987. Compost specifications for the production and characterization of compost from municipal waste. In: Be Bertoldi $M$. et al.,(eds.). Compost: production, qualily and use. Elsevier Applied Science, London, UK. pp. 30-50. 